\title{
TNF-Alpha Serum Level as Prognostic Factor in Pediatric Sepsis Patients
}

\author{
Sitti Aizah Lawang ${ }^{1,3}$, Idham Jayaganda ${ }^{2} \&$ Dasril Daud $^{1,3}$ \\ ${ }^{1}$ Pediatric Department of Faculty Medicine Hasanuddin University, Makassar, Indonesia \\ ${ }^{2}$ Wahidin Sudirohusodo Hospital, Makassar, Indonesia \\ ${ }^{3}$ PostGraduate School Students Faculty of Medicine, Hasanuddin University, Makassar, Indonesia \\ Correspondence: Sitti Aizah Lawang, Department of Pediatrics, Faculty of Medicine, Hasanuddin University, Jl. \\ Perintis Kemerdekaan Km. 10, Tamalanrea Makassar, 90245, Indonesia.
}

Received: March 9, 2021 Accepted: March 29, 2021 Online Published: April 13, 2021

doi:10.5539/gjhs.v13n5p104 URL: https://doi.org/10.5539/gjhs.v13n5p104

\begin{abstract}
Objective: The study aimed to investigate the role of $\mathrm{TNF} \alpha-308$ genetic polymorphism, association between TNF- $\alpha$ serum level and prognostic factor of mortality in pediatric sepsis.

Methods: This was a prospective cohort study. Consecutive sampling method was used and samples were obtained from septic patients diagnosed based on the IPSC 2005 criteria. Serum TNF- $\alpha$ and genetic polymorphism were measuread and analyzed with ELISA and PCR plus sequencing, respectively.

Result: One hundred and seventeen samples were included, 62 were in survivor grioup and 55 in non survivor group. A very significant association was found between TNF- $\alpha$ serum level and mortality $(\mathrm{p}<0.001)$. The optimal cut off point of TNF $\alpha$ serum level as prognostic factor for mortality was $\geq 500 \mathrm{pg} / \mathrm{mL}$ ( $\mathrm{p}<0.001$ and OR 16.6) sensitivity $78.1 \%$, specificity $82 \%$, Positive Predictive Value (PPV) 79.6\%, Negative Predictive Value (NPV) $80.9 \%$, Area Under Curve (AUC) 0.811 . Two samples showed TNF $\alpha-308$ A polymorphism and mutation of GG allele to heterozygote GA allele. Neither TNF $\alpha$ polymorphism and TNF $\alpha$ serum level showed any association with mortality. There was no significant association between TNF $\alpha-308$ polymorphism and TNF- $\alpha$ serum level $\mathrm{p}=0.461(\mathrm{p}>0.05)$ and mortality $\mathrm{p}=0.219(\mathrm{p}>0.05)$, all sample who had TNF $\alpha-308$ genetic polymorphism were in non survivor group and had TNF- $\alpha$ serum level $\geq 500 \mathrm{pg} / \mathrm{mL}$.
\end{abstract}

Conclusion: Genetic polymorphism of TNF- $\alpha-308$ showed no statistic significant on mortality, but all subjects with TNF $\alpha-308$ polymorphism had higher TNF- $\alpha$ serum and were all in non-survivor group.

Keywords: Sepsis, TNF- $\alpha$, TNF $\alpha-308$ genetic polymorphism

\section{Introduction}

Sepsis, which is usually caused by infection can lead to severe systemic inflammation. Severe sepsis and shock sepsis are associated with high mortality rate in intensive care unit. Sepsis related mortality remains as high as $30-50 \%$. Sepsis, severe sepsis, and septic shock are major healthcare problems worldwide; they affect millions of people each year (Feng et al., 2015; Song et al., 2012; Wang et al., 2017; Wu et al., 2019; Zhang et al., 2017).

Sepsis is a clinical syndrome triggered by infection. Clinical manifestations including fever or hypothermia, increased or decreased white blood cell, tachycardia and tachypnea. Bacterial infections are the most common cause of sepsis. It can also caused by fungal, parasitic or viral infections. Several internal and external factors play important role in sepsis. Internal factors such as immune and genetic predisposition could determine the severity of sepsis (Mira et al., 1999; Nasronudin, 2011).

Excessive production of proinflammatory cytokines together with unbalanced production of anti-inlamatory mediators in acute systemic respon is the major pathogenesis of sepsis. The most critical pro-inflamatory cytokines that has important role in pathogenesis of acute inflamatory response is Tumor Necrosis Factor-Alpha (TNF- $\alpha$ ). Tumor necrosis factor- $\alpha$ gene is located at chromosom $6 \mathrm{p} 21.3$ spanning approximately $3 \mathrm{~kb}$ and have 4 exons to produce 212 amino acid. Polymorphic change of TNF- $\alpha$ is associated with increase secretion of TNF- $\alpha$ from macrophage following lipopolisacharide stimulation._Major genetic polymorphism within the regulatory regions of the gene coding for TNF- $\alpha$ gene has been identified $-308(\mathrm{G} \rightarrow \mathrm{A})$. This transition of guanine to adenin at TNF- $\alpha$ 
at the-308 base pair from transcriptional start site was observed in several in-vitro studies. This genetic polymorphism mainly observed in Caucasian population. Genetic polymorphism variation varies between ethnic groups. (Feng et al., 2015; Song et al., 2012; Wang et al., 2017; Wu et al., 2019; Zhang et al., 2017) Our study was conducted on Southeast Asian population in Indonesia, to evaluate the association between TNF- $\alpha-308$ polymorphism and the risk of mortality in pediatric sepsis patients.

\section{Method}

\subsection{Patients and Controls}

This cohort prospective study was conducted in Wahidin Sudirohusodo Hospital, Makassar, Indonesia from December 2018 to Mei 2019. Eligible patients aged 1 month - 18 years with sepsis and shock sepsis admitted to pediatric intensive care unit and emergency room were the inclusion criteria for sampling._Sepsis group was defined by criteria of The International Pediatric Sepsis Consensus (IPSC). Exclusion criteria were trauma, burn, malnourished, longterm corticosteroid use, malignancy and patients with immune deficiency. Septic shock was defined as having systolic blood pressure less than $90 \mathrm{mmHg}$ and CRT $>2$ second. Survivor and - non survivor were defined as septic patients discharge from PICU and those who died in PICU, respectively.

Blood sample was used to analyze TNF- $\alpha$ serum level and TNF- $\alpha-308$ genetic polymorphism. The laboratory test was performed within the first 24 hours after diagnosis was established. All patients were observed until discharged from PICU and the clinical outcome was survivor or non-survivor in PICU.

This study was approved by the internal review board and ethics committee of Hasanuddin University, Makassar, Indonesia. Informed consents were obtained from case and control subjects and/or their parents or guardians

\subsection{Cytokine Serum Consentration}

Cytokine serum consentration TNF- $\alpha$ was determined. Blood was taken by venapuncture and sampled on vacutainers. The blood was then centrifuged and the serum had been frozen $\left(-70^{\circ} \mathrm{C}\right)$ until the time of analysis. Tumour Necrosis Factor- $\alpha$ serum consentration was examined using enzyme-linked immunosorbent assay (ELISA).

\subsection{Analysis of Gene Polymorpism TNF- $\alpha-308$}

To analyze gene polymorphism, a $5 \mathrm{ml}$ sample of EDTA anti-coagulated blood was extracted. The polymerase chain reaction restriction fragment length polymorphism method._The TNF- $\alpha$ gene promoter was amplified by using a modified protocol previously described: TNF- $\alpha$ forward primer (5'- AGG CAA TAG GTT TTG AGG GCC AT - 3') and TNF- $\alpha$ reverse primer (5'- ACA AGC ATC AAG GAT ACC CCT - 3'). The volume for the PCR mixture $50 \mathrm{uL}, 10 \mathrm{X}$ PCR buffer $5 \mathrm{uL}, 25 \mathrm{mM} \mathrm{MgCl}_{2} 2 \mathrm{uL}, 5 \mathrm{mM}$ dNTP $1 \mathrm{uL}$, Reverse primer (20pmol) $1 \mathrm{uL}$, Forward primer (20pmol) $1 \mathrm{uL}$, Hotstart DNA pol. $0.25 \mathrm{uL}$, DNA sample $5 \mathrm{uL}$, ddH2O $34.75 \mathrm{uL}$.

Amplification was performed with PCR machine (DNA thermal Cycler). Initial steps were denaturation at $95{ }^{\circ} \mathrm{C}$ for 15 minutes, continued at $94^{\circ} \mathrm{C}$ for 1 minute, annealing at $55^{\circ} \mathrm{C}$ for 30 seconds, extention at $72^{\circ} \mathrm{C}$ for 1.5 minute at 45 cycles, followed by final extention at $72^{\circ} \mathrm{C}$ for 10 minutes and at $12{ }^{\circ} \mathrm{C}$ for approximately 30 minutes before storage.

Digested PCR fragments were analyzed by electrophoresis in a 3\% agarose gel, visualized by ethidium bromide staining.

\subsection{Sequencing}

Mutation was analysed with direct sequencing in Laboratorium $1^{\text {st }}$ Base Malaysia. To detect mutation in TNF- $\alpha$ gene from the sequencing PCR product, "Bioedit" software was used. The results were then compared with data from "Gene Bank" at NCBI data base with Basic Local Alignment Search Tool (BLAST) method

\subsection{Data Analysis}

Result from DNA sequencing in form of electropherogram was then aligned with normal sequence from Gene Bank and was analysed with Bioedit software Sequence Alignment Editor version 7.0.5.1.

\subsection{Statistics Analysis}

Univariate analysis was used for descriptive data such as frequency, mean, range and standar deviation. Student t test and Mann Whitney test for bivariate analysis were used to compare continous variables with normal- and not normal distribution, respectively. Correlation studies between different groups were analyzed using chi-square test. Receiver Operator Curve (ROC) was used to determine the prognostic cut off point of TNF- $\alpha$ serum level followed by sensitivity and specificity calculation._A p-value of less than 0.05 was considered statistically significant. The 
risk of mortality was estimated by odds ratio with $95 \%$ confidence intervalResult from DNA sequencing in form of elektrophenogram and than aligned with normal sequence from Gene Bank and than analysed with Bioedit software Sequence Alignment Editor versi 7.0.5.1.

\section{Results}

Between December 2018 and Mei 2019, 117 sepsis patients aged 1 month to 18 years were included. Of this number, 68 and 49 were sepsis and shock sepsis patients, respectively. There were $62(53 \%)$ survivor and 55 (47\%) non-survivor. Male and female subjects were $75(64.1 \%)$ and $42(35.9 \%)$, respectively.

\subsection{Characteristics of the Subjects}

Table 1. Characteristic of the Subject

\begin{tabular}{|c|c|c|c|}
\hline Characteristics & $\begin{array}{l}\text { Survivor } \\
(\mathrm{n}=62)\end{array}$ & $\begin{array}{l}\text { Non-survivor } \\
(n=55)\end{array}$ & $\mathbf{P}$ \\
\hline \multicolumn{3}{|l|}{ Gender } & \multirow{3}{*}{$0.628^{*}$} \\
\hline Male & $41(54.7 \%)$ & $34(45.3 \%)$ & \\
\hline Female & $21(50 \%)$ & $21(50 \%)$ & \\
\hline Age (year) & \multirow{2}{*}{6.26} & \multirow{2}{*}{4.45} & \multirow{5}{*}{$0.087^{* *}$} \\
\hline Mean & & & \\
\hline Median & 4.25 & 2.00 & \\
\hline Standard Deviation & 5.69 & 5.26 & \\
\hline Min-max & $0.08-16.33$ & $0.08-17.91$ & \\
\hline \multicolumn{4}{|c|}{ Primary site of infection (n) } \\
\hline Respiratory tract & 33 & 34 & \\
\hline Neurologic system & 18 & 17 & \\
\hline Gastrointestinal tract & 3 & 2 & \\
\hline Renal disease & 2 & 2 & \\
\hline Dengue infection & 4 & & \\
\hline Metabolic & 1 & & \\
\hline Skin infection & 1 & & \\
\hline \multicolumn{4}{|l|}{ Culture } \\
\hline Positive & $6(50 \%)$ & $6(50 \%)$ & \\
\hline Negative & $49(47 \%)$ & $56(53 \%)$ & $0.827^{*}$ \\
\hline
\end{tabular}

*Chi-square test.

** Mann-Whitney Test.

There were no significant differences in gender, age, and culture with $\mathrm{p}>0.05$. Only 12 patients showed growth in culture. Gram negative bacteria growth were observed in most of the cultures. 
Table 2. Culture result in survivor and non survivor group

\begin{tabular}{lllll}
\hline No & Culture & Bacteria & Survivor & Non-Survivor \\
\hline 1. & Burkholderia Cepacia & Neg & 3 & 0 \\
2. & Klebsiella Pneumonie & Neg & 2 & \\
3. & E.Coli & Neg & 1 & 1 \\
4. & Acinetobacter Baumanii & Neg & & 2 \\
5. & Staphylococcus Hominis & Pos & & 2 \\
6. & Enterobacter & Neg & & 1 \\
& Total & & 6 & 6 \\
\hline
\end{tabular}

Burkholderia Cepacia was the most common bacteria in survivor group but acinetobacter baumanii and staphylococcus Hominis were the most common bacteria in non survivor group

\subsection{Parameters and Biomarker in Survive and Non-Survive Sepsis Patients}

Table 3. Parameters and biomarker value in survivor and non survivor sepsis patients

\begin{tabular}{|c|c|c|c|}
\hline \multirow{3}{*}{ Parameter } & \multicolumn{2}{|c|}{ Sepsis } & \multirow{3}{*}{ P Value } \\
\hline & Survivor & Non-Survivor & \\
\hline & $\mathrm{n}=62$ & $\mathrm{n}=55$ & \\
\hline \multicolumn{4}{|l|}{ WBC (mg/dL) } \\
\hline Mean & 9,808 & 22,050 & \\
\hline Median & 16,550 & 21,250 & $0.264^{*}$ \\
\hline Standard Deviation & 12,876 & 11,243 & \\
\hline Minimum-maximum & $3640-61,730$ & $3100-55,200$ & \\
\hline \multicolumn{4}{|l|}{$\mathrm{CRP}(\mathrm{mg} / \mathrm{dL})$} \\
\hline Mean & 44.47 & 68.70 & \\
\hline Median & 21.70 & 40.00 & $0.056^{*}$ \\
\hline Standard Deviation & 57.44 & 79.43 & \\
\hline Minimum-maximum & $0-238$ & $0-289$ & \\
\hline \multicolumn{4}{|l|}{ Procalcitonin(ng/ml) } \\
\hline Mean & 15.78 & 43.64 & \\
\hline Median & 2.41 & 16.60 & $0.007 *$ \\
\hline Standard Deviation & 36.79 & 66.21 & \\
\hline Minimum-maximum & $0.01-210$ & $0.19-210$ & \\
\hline \multicolumn{4}{|l|}{ TNF- $\alpha(\mathrm{pg} / \mathrm{ml})$} \\
\hline Mean & 427.25 & 848.92 & \\
\hline Median & 413.49 & 825.07 & $<0.001 *$ \\
\hline Standard Deviation & 111.49 & 358.06 & \\
\hline Minimum-maximum & $195.26-1009.17$ & $231.11-1784.68$ & \\
\hline
\end{tabular}

*Mann Whitney Test.

There were significant difference in procalcitonin $(\mathrm{p}=0.007)$ and TNF- $\alpha(\mathrm{p}<0.001)$ between sepsis survivor and non survivor with $\mathrm{p}<0.05$. 


\subsection{Multivariat Analysis of Parameters and Biomarker in Survivor and Non-Survivor Sepsis Patients}

Table 4. Multiple Logistic Regression Analysis of parameters and biomarker in survivor and non-survivor group

\begin{tabular}{lllllll}
\hline No & Variable & B & S.E & $\mathrm{p}$ & AOR & $95 \%(\mathrm{CI})$ \\
\hline 1. & Procalcitonin & 0.009 & 0.005 & 0.072 & 1.009 & $0.99-1.019$ \\
2. & TNF- $\alpha$ & 0.008 & 0.002 & $<0.001$ & 1.008 & $1.005-1.012$ \\
\hline
\end{tabular}

The result of multiple logistic regression analysis, only 1 variable which is TNF- $\alpha$ as independent factor for outcome of sepsis with $\mathrm{p}<0.001$ AOR 1.008 (1.005-1.012)

\subsection{Mortality Cutt off Point of TNF- $\alpha$ in Sepsis Patients}

Receiver operating characteristic curve evaluate the level of TNF- $\alpha$ in predicting mortality in pediatric sepsis. The ROC curve showed the optimal cut off point of TNF- $\alpha$ level for mortality prediction in pediatric sepsis was 500 $\mathrm{pg} / \mathrm{ml}$ with the largest area under curve (AUC) 0.811 .

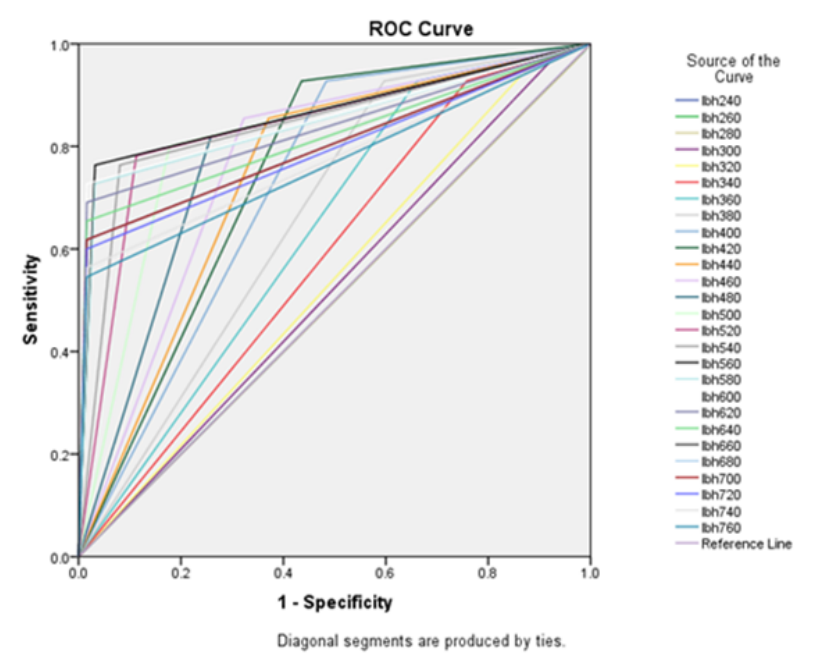

Figure 1. ROC Curve

Table 5. Prognostic value of TNF- $\alpha$ serum $\geq 500 \mathrm{pg} / \mathrm{mL}$

\begin{tabular}{lrrrrrrr}
\hline \multirow{2}{*}{ TNF $\alpha(\mathrm{pg} / \mathrm{mL})$} & \multicolumn{4}{c}{ Sepsis } & \multicolumn{2}{c}{ Total } \\
\cline { 2 - 6 } & \multicolumn{2}{c}{ Non-Survivor } & \multicolumn{2}{c}{ Survivor } & \multicolumn{2}{c}{} \\
\cline { 2 - 6 } & $\mathrm{n}$ & $\%$ & $\mathrm{n}$ & $\%$ & $\mathrm{n}$ & $\%$ \\
\hline 500 & 43 & $79.6 \%$ & 11 & $20.4 \%$ & 54 & $100 \%$ \\
$<500$ & 12 & $19 \%$ & 51 & $81 \%$ & 63 & $100 \%$ \\
Total & 55 & $47 \%$ & 62 & $53 \%$ & 117 & $100 \%$ \\
\hline
\end{tabular}

Chi-square, $\mathrm{X}^{2} ; \mathrm{OR}=16.6, \mathrm{df}=1 ; \mathrm{p}<0.001$.

The sensitivity of TNF- $\alpha$ serum level $\geq 500 \mathrm{pg} / \mathrm{mL}$ was $78.1 \%$, with $82 \%$ specificity. Positive predictive value was $79.6 \%$, and negative predictive value was $80.9 \%$ with $95 \% \mathrm{CI}(\mathrm{p}<0.001)$, area under curve (AUC) 0.811 and $\mathrm{OR}=16.6$.

3.5 Association between TNF $\alpha-308$ Genetic Polymorphism and TNF- $\alpha$ Serum Level

There were 2 patients with G/A allele TNF $\alpha-308$ genetic polymorphism but no patient with A/A allele genetic polymorphism was observed. Mean serum level of TNF- $\alpha$ in sepsis patient with TNF $\alpha-308$ genetic polymorphism was $788.88(767.54-810.23) \mathrm{pg} / \mathrm{mL}$ and in patiens with no genetic polymorphism was $612.67 \mathrm{pg} / \mathrm{mL}$ 
(195.26-1784.68) $\mathrm{pg} / \mathrm{mL}$. The student $\mathrm{t}$ test showed no significance different in two groups with $\mathrm{p}=0.461$ $(\mathrm{p}>0.05)$.

Table 6. Mean TNF- $\alpha$ serum level between sepsis patients with TNF- $\alpha 308$ (G/A) genetic polymorphism and without genetic polymorphism

\begin{tabular}{lll}
\hline & \multicolumn{2}{c}{ Sepsis } \\
\cline { 2 - 3 } TNF- $\alpha-308(\mathrm{G} / \mathrm{A})(\mathrm{pg} / \mathrm{mL})$ & Without Polimorphysm & Polimorphysm \\
& $\mathrm{n}=115$ & $\mathrm{n}=2$ \\
\hline Mean & 612.67 & 788.88 \\
Median & 485.80 & 788.88 \\
Standard deviation & 335.72 & 30.18 \\
Minimum-maximum & $195.26-1784.68$ & $767.54-810.23$ \\
\hline
\end{tabular}

Student T-Test; $\mathrm{p}=0.461(\mathrm{p}>0.05)$.

\subsection{Association between TNFa- 308 Genetic Polymorphism and Sepsis Outcome}

There was no patient detected of having TNF $\alpha-308$ genetic polymorphism in the survivor group. In non-survivor group two $(100 \%)$ patients was observed to have genetic polymorphism. In group with no TNF $\alpha-308$ genetic polymorphism, there were $62(53.9 \%)$ survivor and $53(47 \%)$ non-survivor. Statistical analysis showed no significant difference between two groups with $\mathrm{p}=0.219(p>0.05)$.

Table 7. Relation Genetic polymorphism TNF $\alpha-308$ with sepsis outcome

\begin{tabular}{lllc}
\hline \multirow{2}{*}{$\begin{array}{lll}\text { Polimorphysm } \\
\text { TNF } \alpha-308(\mathrm{G} / \mathrm{A})\end{array}$} & Sepsis & Non-Survivor & Total \\
\cline { 2 - 4 } & Survivor & $\mathrm{n}=55$ & $2(100 \%)$ \\
\hline Polimorphysm & $0(0 \%)$ & $2(100 \%)$ & $115(100 \%)$ \\
Without Polimorphysm & $62(53.9 \%)$ & $53(46.1 \%)$ & $117(100 \%)$ \\
Total & $62(53 \%)$ & $55(47 \%)$ & \\
\hline
\end{tabular}

Fisher exact test; $\mathrm{p}=0.219(\mathrm{p}>0.05)$.

\section{Discussion}

Culture results showed mainly negative bacteria growth. Acinetobacter baumanii and staphylococcus Hominis were the most common cause of mortality in this study. There was no significant difference between positive culture and negative culture related to sepsis outcome with $p=0.827(p>0.05)$. The gram-negative bacteria, highly resistence to antibiotic, were the most common bacteria in PICU. Resistance mechanism of gram-negative bacteria from $\beta$ lactam antibiotics, because gram-negative bacteria produce $\beta$ lactamase enzyme. The small sample with growth in culture can cause no significance difference in patients outcome.

Two parameters appear to satistically significant on sepsis outcome were procalcitonin $(p=0.007)$ and TNF- $\alpha$ $(\mathrm{p}=0.000)$. However, in multivariate analysis only TNF- $\alpha$ showed significance difference. Procalcitonin known as a marker to establish bacterial infection, but the number of positive growth culture in this study is very few.

After multivariate logistic regression analysis was performed, only TNF- $\alpha$ acts as independent factor related to sepsis outcome $\mathrm{p}<0.001$, AOR 1.008 (1.005-1.012). The mean value of TNF- $\alpha$ in survivor group was 416.66 and in non-survivor group was 835.25. (Tables 3-4)

Invasion from pathogenic microorganism and their product will stimulate proinflammatory cytokine. Major proinlamatory cytokine that has important role in sepsis pathogenesis are TNF- $\alpha$, IL-1, IL-6 and IL-8. Sepsis indicates that the profound proinflammatory response is counteracted by certain anti-inflammatory cytokines, including IL-10, transforming growth factor (TGF)- $\beta$, and IL-4, which attempt to restore immunological 
equilibrium. Uncontrolled activation of the inflammatory system in response to an invading pathogen can result in multiorgan failure and eventually death. (Sabelnikovs et al., 2012)

ROC curve showed optimal cut off point with the biggest AUC for TNF- $\alpha$ level as prognostic factor for mortality in pediatric sepsis was $\geq 500 \mathrm{pg} / \mathrm{mL}$ and AUC 0.811 With this cut off point the sensitivity was $78.1 \%$, specificity was $82 \%$, positive predictive value and negative predictive value were $79.6 \%$ and $80.9 \%$, respectively; with $95 \%$ CI $(p<0.001)$, area under curve (AUC) 0.811 and OR 16.6. This cut off point level were depended on duration of disease, severity of disease and the frequency of exposure to infection.

Genetic polymorphism -308 in TNF- $\alpha$ means that the transition of guanin to adenin located the -308 base pair at promoter gene in transcription phase. Allele at promoter gene -308 is GG, in case of polymorphism, allele can change to heterozygote GA or homozygote AA. The $-308 \mathrm{~A} / \mathrm{G}$ polymorphism in the TNF- $\alpha$ gene has been shown to up regulated the gene transcription, leading to higher levels of expressed protein in serum. Elevated TNF- $\alpha$ levels enhance the inflamatory response and lead to multiple phenotypic and induce apoptosis and decrease immune respons and cell function (Teuffel et al., 2010)

Genetic polymorphism is related to ethnic. Mainly observed in Caucasian population. In this study, only 2 patients showed TNF- $\alpha-308$ genetic polymorphism G/A allele and none with A/A allele. A Thailand study conducted by Phumeetham et al. represented Southeast Asian population. The study observed that TNF- $\alpha-308$ genetic polymorphism, found in 8 patients from 66 sepsis/septic shock patients, had no association with the risk and severity of sepsis or septic shock in Thai population (Phumeetham et al., 2012)

In this study patient with TNF $\alpha-308$ genetic polymorphism had mean TNF $\alpha$ level of 788.88 (767.54-810.23) pg/ml and those with no genetic polymorphism had mean TNF $\alpha$ level of 612.67 (195.26-1784.68) pg/ml. Statistical analysis with $\mathrm{X}^{2}$ test showed no significant difference in these two groups with $\mathrm{p}=0.461(\mathrm{p}>0.05)$. Although statistical analysis showed no significancy but the two patients with TNF $\alpha-308$ genetic polymorphism both had $\mathrm{TNF} \alpha$ level more than $500 \mathrm{pg} / \mathrm{ml}$ (the cut off point for mortality in pediatric sepsis.)

Outcome from sepsis patients with TNF $\alpha-308$ genetic polymorphism are survive $0(0 \%)$ and non-survivor 2 (100\%). In patients without TNF $\alpha-308$ genetic polymorphism, there were $62(53.9 \%)$ and $53(47 \%)$ survivor and non-survivor, respectively. Statistical analysis showed no significant difference between the 2 groups with $\mathrm{p}=0.219$ $(\mathrm{p}>0.05)$. Incidence of polymorphism in population is about $1 \%$. In this study, from 117 samples only 2 patients have TNF $\alpha-308$ genetic polymorphism, and all has heterozygote GA, none has AA allele, so the influence is very small or sublethal.

The limitation of this study are the method was not multi centre study along with small sample size with various kind of diseases. Studies with large samples, as well as more specified disease, are needed to demonstrate the results of this study more clearly and definitively.

\section{Competing Interests Statement}

The authors declare that there are no competing or potential conflicts of interest.

\section{References}

Feng, B., Mao, Z., Pang, K., Zhang, S., \& Li, L. (2015). Association of tumor necrosis factor $\alpha-308 \mathrm{G} / \mathrm{A}$ and interleukin-6 -174G/C gene polymorphism with pneumonia-induced sepsis. Journal of Critical Care, 30(5), 920-923. https://doi.org/10.1016/j.jcrc.2015.04.123

Mira, J. P., Cariou, A., Grall, F., Delclaux, C., Losser, M. R., Heshmati, F., Cheval, C., Monchi, M., Teboul, J. L., Riché, F., Leleu, G., Arbibe, L., Mignon, A., Delpech, M., \& Dhainaut, J. F. (1999). Association of TNF2, a TNF-alpha promoter polymorphism, with septic shock susceptibility and mortality: a multicenter study. JAMA, 282(6), 561-568. https://doi.org/10.1001/jama.282.6.561

Nasronudin. (2011). Penyakit Infeksi di Indonesia dan Solusi Kini dan Mendatang (2nd ed.).

Phumeetham, S., Chat-Uthai, N., Manavathongchai, M., \& Viprakasit, V. (2012). Genetic association study of tumor necrosis factor-alpha with sepsis and septic shock in Thai pediatric patients. Jornal de Pediatria, 88(5), 417-422. https://doi.org/10.2223/JPED.2216

Sabelnikovs, O., Nikitina-Zake, L., Krumina, A., Jaunberga, Z., Klovins, J., Viksna, L., Bjertnaes, L. J., Kovalchuka, L., \& Vanag, I. (2012). Associations between TNF- $\alpha$, IL-6 and IL-10 Promoter Polymorphisms and Mortality in Severe Sepsis. Journal of Scientific Research and Reports, 1(1), 17-28. https://doi.org/10.9734/jsrr/2012/1758

Song, Z., Song, Y., Yin, J., Shen, Y., Yao, C., Sun, Z., Jiang, J., Zhu, D., Zhang, Y., Shen, Q., Gao, L., Tong, C., \& 
Bai, C. (2012). Genetic variation in the TNF gene is associated with susceptibility to severe sepsis, but not with mortality. PloS One, 7(9), e46113. https://doi.org/10.1371/journal.pone.0046113

Teuffel, O., Ethier, M.-C., Beyene, J., \& Sung, L. (2010). Association between tumor necrosis factor-alpha promoter $-308 \mathrm{~A} / \mathrm{G}$ polymorphism and susceptibility to sepsis and sepsis mortality: a systematic review and meta-analysis. Critical Care Medicine, 38(1), 276-282. https://doi.org/10.1097/CCM.0b013e3181b42af0

Wang, H., Guo, S., Wan, C., Yang, T., Zeng, N., Wu, Y., Chen, L., Shen, Y., \& Wen, F. (2017). Tumor necrosis factor- $\alpha-308 \mathrm{G} / \mathrm{A}$ polymorphism and risk of sepsis, septic shock, and mortality: an updated meta-analysis. Oncotarget, 8(55), 94910-94919. https://doi.org/10.18632/oncotarget.20862

Wu, Y., Wu, C., Zhang, S., Wu, D., \& Zhong, Y. (2019). Tumor Necrosis Factor- $\alpha$-308G/A Genetic Polymorphism and the Susceptibility of Posttraumatic Sepsis. International Surgery, 104(5-6), 291-296. https://doi.org/10.9738/intsurg-d-19-00016.1

Zhang, Y., Cui, X., Ning, L., \& Wei, D. (2017). The effects of tumor necrosis factor- $\alpha$ (TNF- $\alpha$ ) rs 1800629 and rs361525 polymorphisms on sepsis risk. Oncotarget, 8(67), 111456-111469. https://doi.org/10.18632/oncotarget.22824

\section{Copyrights}

Copyright for this article is retained by the author(s), with first publication rights granted to the journal.

This is an open-access article distributed under the terms and conditions of the Creative Commons Attribution license (http://creativecommons.org/licenses/by/4.0/). 